\title{
Effect of Turmeric (Curcuma longa) Powder and Synbiotic as Alternative to Antibiotic Growth Promoter on the Growth Performance and Mortality of Broiler Chicks
}

\author{
Manish Kumar Nagar ${ }^{1}$, Kavita Shende ${ }^{2 *}$, Rajesh Kumar Dhuria ${ }^{3}$, Hakim Manzer ${ }^{4}$ and Surendra $^{5}$ \\ ${ }^{1}$ Department of Animal Nutrition, CVAS, Navania, Udaipur, Rajasthan, University of Veterinary E Animal Sciences, \\ Bikaner, Rajasthan, INDIA \\ ${ }^{2}$ Department of Animal Nutrition, CVAS, Navania, Udaipur, Rajasthan, University of Veterinary E Animal Sciences, \\ Bikaner, Rajasthan, INDIA \\ ${ }^{3}$ Department of Animal Nutrition, CVAS, Bikaner, University of Veterinary \& Animal Sciences, Bikaner, Rajasthan, INDIA \\ ${ }^{4}$ Department of Veterinary Parasitology, CVAS Navania, Udaipur, University of Veterinary E Animal Sciences, \\ Bikaner, Rajasthan, INDIA \\ ${ }^{5}$ Department of Veterinary Public Health, CVAS, Navania, Vallabhnagar, Udaipur, University of Veterinary \& Animal Sciences, \\ Bikaner, Rajasthan, INDIA \\ "Corresponding author: K Shende; E-mail: dr.kavitashende@gmail.com
}

Received: 26 Dec., 2020

Revised: 21 Jan., 2021

Accepted: 29 Jan., 2021

\begin{abstract}
The objective of the study was to investigate the effect of turmeric (Curcuma longa) powder and synbiotic as alternative to antibiotic growth promoter on growth performance of broiler chicks. Total 150 day-old chicks were purchased and randomly divided into 5 treatments having 30 chicks in each group with three replicates of 10 chicks in each. The five dietary treatments were designated as $\mathrm{T}_{1}$ control group (basal diet), $\mathrm{T}_{2}$ supplemented with antibiotic @ $0.02 \%$ level, $\mathrm{T}_{3}$ supplemented with turmeric @ $0.5 \%$ level, $\mathrm{T}_{4}$ supplemented with synbiotic@0.05\% level and $\mathrm{T}_{5}$ supplemented with turmeric @ 0.25\% + synbiotic @ $0.025 \%$ in the diet. Highly significant $(\mathrm{P}<0.01)$ effect of dietary treatment was observed on growth performance and mortality percent as compared to control and antibiotic supplemented group. Highest body weight was observed in $\mathrm{T}_{5}$ group and lowest in control group. Body weight gain, daily weight gain, feed consumption and performance index was found significantly $(\mathrm{P}<0.01)$ higher in $\mathrm{T}_{5}$ group which was comparable with $\mathrm{T}_{4}$ group and lowest was recorded in control group which showed non-significant difference with $\mathrm{T}_{2}$ group i.e. antibiotic supplemented group. Significantly $(\mathrm{P}<0.01)$ lowest feed conversion ratio and highest protein efficiency ratio was observed in $\mathrm{T}_{5}$ group as compared to control group. Mortality was reduced in all treatment groups as compared to control group. It can be concluded that as an alternative to antibiotics, turmeric plus synbiotic supplementation can be used to increase the growth performance and livability of broiler chicken in the post-antibiotic period.
\end{abstract}

\section{HIGHLIGHTS}

(0 Turmeric powder and synbiotic as alternative to antibiotic growth promoter significantly improved growth performance of broilers.

(0 Turmeric powder and synbiotic as alternative to antibiotic growth promoter significantly reduced mortality percent of broilers.

Keywords: Turmeric, synbiotic, antibiotic growth promoter, broiler

Today, poultry farming goes about as salary stabilizer as well as gives ordinary and convenient pay compared to the cultivation of crops and other domesticated animals. In poultry nutrition, feeding costs are considered the mostcostly element in the entire cycle of production. Feed is a
How to cite this article: Nagar, M.K., Shende, K., Dhuria, R.K., Manzer, H. and Surendra. (2021). Effect of turmeric (Curcuma longa) powder and synbiotic as alternative to antibiotic growth promoter on the growth performance and mortality of broiler chicks. J. Anim. Res., 11(1): 167-172. Source of Support: None; Conflict of Interest: None क्? 
significant segment that influences the net income of the poultry business in the light of the fact that $70 \%$ of absolute consumption is in terms of money spent on feed purchase (Willems et al., 2013). At the same time as making gains in production and efficiency, the industry needed to enhance the well-being and prosperity of birds and minimize the impact of the industry on the environment. The use of feed additives has been an important part of making progress in promoting growth, protecting well-being and optimizing the genetic potential of modern broiler and layer hybrid growth promoter feed additives used in poultry diets (Dhama et al., 2011; Youssef et al., 2013). There are different types of growth promoters used in the broiler industry such as antibiotics, probiotics, prebiotics, exogenous enzymes, antioxidants, coccidiostats, etc. (Dhama et al., 2011; Angelakis et al., 2013) and other novel growth promoters include herbs, panchgavya, elements and certain other nutritional substances (Mahima et al., 2012, 2013; Dhama et al., 2013).

The indiscriminate use of antibiotics as feed additives in poultry farms has increased public health wariness about the development of resistant strains of pathogenic bacteria (Abd El-Moneim et al., 2020; Abd El-Moneim and Sabic, 2019) and residual contamination of poultry products (Shewita and Taha, 2018; Alagawany et al., 2019a; Soomro et al., 2019). Banning antibiotic growth promoters from the markets of the European Union and many other countries has challenged poultry producers to find appropriate alternative option to AGP (Abdelnour et al., 2019; Alagawany et al., 2019b).

Turmeric rhizome (Curcuma longa) is a perpetual rhizomatous plant of the ginger family, Zingiberaceae is a widely used spice, food preservative and coloring material that has biological actions and medicinal uses (Akbarian et al., 2012) has a positive effect on the performance of broilers and a lowering effect on blood serum cholesterol, triglycerides (Hussein, 2013). Beneficial effects of bioactive plant substances in animal nutrition may include appetite stimulation and feed intake, improvement of endogenous digestive enzyme secretion, activation of immune responses, and antibacterial, antiviral and antioxidant action (Hosseini-Vashan et al., 2012). Curcumin is the main important bioactive ingredient responsible for biological activity of curcuma longa (Nouzarian et al., 2011) when compared to commercially available antibiotics, turmeric is a safe, non-toxic and ideal food additive widely used in daily diet.

Animals needs to maintain specific numbers of beneficial microbiota in the gastrointestinal tract to ensure that the animal has the proper microbial balance at all times (Abd El-Hack et al., 2018; Alagawany et al., 2018; Arif et al., 2019). Therefore, adding the probiotics to the bird's diet improves their utilization (Alagawany et al., 2016; Farghly et al., 2018; Taha et al., 2019) because probiotics can neutralize and stabilize the gut ecosystem, compete for the enteric pathogens for nutrients and intestinal attachment sites, inhibit pathogenic adhesion, inhibit epithelial invasion, prevent common intestinal clinical signs, promote the metabolic processes of digestion and absorption of nutrients and supply the birds with several substrates that enhance their immune response. Numerous bifidobacteria and Bacillus strains have been used as alternatives for chemotherapeutic agents in poultry, animals, and humans (Dankowiakowska et al., 2013; Kantas et al., 2015). On the other hand, prebiotics are indigestible food additives which help the host by selectively promoting the production and activity of live microbials in the host's gut and thus improving their health and longevity. The combination of prebiotics and probiotics in poultry nutrition giving energy and net health benefits to the host is referred to as synbiotic. This combined effect could enhance the survival and persistence of the healthpromoting organism in the intestine of birds and could be used as an option for AGP due to its availability as a specific fermentation substrate and the synergistic action of both probiotics and prebiotics (Adil and Magray 2012; Aziz Mousavi et al., 2015). Consequently, the required combination of the two components in a single product would ensure a superior impact compared to the probiotic or prebiotic action alone. Keeping the aforementioned realities in view, the present study was planned to describe the effect of turmeric powder and synbiotic as alternative to antibiotic growth promoter on the growth performance and mortality broiler chicks.

\section{MATERIALS AND METHODS}

One hundred and fifty day-old, unsexed, apparently healthy broiler chicks procured from commercial hatchery were divided into 5 treatments and each treatment of 30 chicks was subdivided into three replicates having 10 chicks each. 
The broiler chicks were vaccinated for Ranikhet Disease (F1 strain) on $7^{\text {th }}$ day and Infectious Bursal Disease (IBD) on $14^{\text {th }}$ day. Broilers were maintained under standard management practices regarding brooding, feeding and watering throughout the trial period. The fresh and dry wheat straw was used as bedding material. Ad lib., access to water and feed was arranged for all the treatments. Commercially available ready-made broiler starter and broiler finisher feed were procured and feed additives such as antibiotic, turmeric (Curcuma longa) and synbiotic were supplemented. The experimental feed will be analyzed for proximate principles by procedure of AOAC (2016). The five dietary treatments were designated as $T_{1}$ control group (basal diet), $\mathrm{T}_{2}$ supplemented with antibiotic @ 0.02\% level, $\mathrm{T}_{3}$ supplemented with turmeric @ 0.5\% level, $\mathrm{T}_{4}$ supplemented with synbiotic@0.05\% level and $\mathrm{T}_{5}$ supplemented with turmeric @ $0.25 \%$ + synbiotic (a) $0.025 \%$ in the diet. The experimental birds were randomly assigned to diets and fed ad-libitum. During the experimental period the growth parameters such as body weight, body weight gain, average daily weight gain, feed consumption, feed conversation ratio, performance index and protein efficiency ratio of birds were evaluated. The chicks were weighed separately at the beginning of the experiment and then at weekly intervals for 6 weeks in the morning before feeding. Live weight gain at weekly interval was calculated from difference in body weight attained between the two consecutive weeks and average daily body weight gain was estimated by dividing the total body weight gain by number of days. Feed conversion ratio (FCR) was calculated as the total feed consumption divided by weight gain in each replication. Performance index was constructed for each treatment by dividing the average weight gain by respective feed conversion ratio and the weight gain of chicks divided by protein consumed on the basis of dry matter was calculated as the protein efficiency ratio. Percent mortality is a measure of the number of deaths in a particular population. The birds in the experiment were routinely monitored for any death or illness to calculate the mortality rate.

\section{Statistical analysis}

The Data belonging to all parameters were subjected statistical analysis by implementing standard methods of variance analysis as defined by statistical package for social science (SPSS), version 20. The significance of the mean difference was checked by Duncan's New Multiple Range Test (DNMRT) as modified by Kramer (1956).

\section{RESULTS AND DISCUSSION}

\section{Growth performance}

The results of growth parameters of six week old broiler chicks are presented in Table (1). The statistical analysis of data showed highly significant $(\mathrm{P}<0.01)$ effect on growth performance with incorporation of turmeric and synbiotic as alternative to antibiotic growth promoter.

Highest body weight was observed in $\mathrm{T}_{5}$ group and lowest body weight was observed in $\mathrm{T}_{1}$ group i.e. control group.

Table 1: Effect of turmeric and synbiotic as alternative to antibiotic growth promoter on growth performance of broilers

\begin{tabular}{lllllll}
\hline \multirow{2}{*}{ Parameters } & \multicolumn{5}{c}{ Treatment groups $^{*}$} \\
\cline { 2 - 7 } & $\mathbf{T}_{1}$ & $\mathbf{T}_{2}$ & $\mathbf{T}_{3}$ & $\mathbf{T}_{4}$ & $\mathbf{T}_{5}$ & SEM \\
\hline Body weight (g) & $2004.37^{\mathrm{a}}$ & $2098.85^{\mathrm{b}}$ & $2185.10^{\mathrm{c}}$ & $2349.14^{\mathrm{d}}$ & $2392.94^{\mathrm{e}}$ & 3.53 \\
Body weight gain (g) & $1965.58^{\mathrm{a}}$ & $1926.90^{\mathrm{a}}$ & $2146.27^{\mathrm{b}}$ & $2309.41^{\mathrm{bc}}$ & $2353.41^{\mathrm{c}}$ & 59.84 \\
Average daily body weight gain (g) & $46.80^{\mathrm{a}}$ & $46.18^{\mathrm{a}}$ & $51.11^{\mathrm{b}}$ & $54.99^{\mathrm{bc}}$ & $56.04^{\mathrm{c}}$ & 1.29 \\
Feed consumption (g) & $3742.44^{\mathrm{a}}$ & $3750.07^{\mathrm{a}}$ & $3820.74^{\mathrm{b}}$ & $3916.90^{\mathrm{c}}$ & $3911.87^{\mathrm{c}}$ & 10.48 \\
Feed conversion ratio & $1.80^{\mathrm{d}}$ & $1.71^{\mathrm{c}}$ & $1.68^{\mathrm{b}}$ & $1.60^{\mathrm{a}}$ & $1.58^{\mathrm{a}}$ & 0.01 \\
Performance index & $1098.01^{\mathrm{a}}$ & $1135.15^{\mathrm{a}}$ & $1277.86^{\mathrm{b}}$ & $1450.95^{\mathrm{c}}$ & $1493.66^{\mathrm{c}}$ & 34.66 \\
Protein efficiency ratio & $2.64^{\mathrm{a}}$ & $2.76^{\mathrm{b}}$ & $2.80^{\mathrm{b}}$ & $3.01^{\mathrm{c}}$ & $3.05^{\mathrm{c}}$ & 0.02 \\
\hline
\end{tabular}

Note: $\mathrm{a}, \mathrm{b}, \mathrm{c}, \mathrm{d}$, e- means superscripted with different letters within a column differ significantly from each other; $\mathrm{T}_{1}:$ Control; $\mathrm{T}_{2}$ : Antibiotic @ $0.02 \% ; \mathrm{T}_{3}$ : Turmeric powder @ 0.5\%; T. Synbiotic@0.05\%; T : Turmeric @ 0.25\%+Synbiotic @ 0.025\%. 
The body weight gain and daily body weight gain were significantly highest in $\mathrm{T}_{5}$ group which was comparable with $\mathrm{T}_{4}$ group and the lowest was found in $\mathrm{T}_{2}$ group i.e. antibiotic supplemented group which was comparable with $\mathrm{T}_{1}$ group. Highest feed consumption was observed in $\mathrm{T}_{4}$ group which showed non-significant difference with the $\mathrm{T}_{5}$ group and lowest feed consumption was observed in $T_{1}$ group and showed non-significant difference with $\mathrm{T}_{2}$ group. Lowest feed conversion ratio was observed in $\mathrm{T}_{5}$ group supplemented with $0.25 \%$ turmeric $+0.025 \%$ synbiotic powder and showed non-significant difference with $\mathrm{T}_{4}$ group and highest feed conversion ratio was observed in $\mathrm{T}_{1}$ group fed with basal feed without addition of turmeric and synbiotic powder. Highest performance index was recorded in $\mathrm{T}_{5}$ group which was comparable with $\mathrm{T}_{4}$ group and lowest performance index was observed in $T_{1}$ group which showed non-significant difference with $\mathrm{T}_{2}$ group. Highest protein efficiency ratio was observed in $\mathrm{T}_{5}$ group which was comparable with $\mathrm{T}_{4}$ group and lowest was observed in $T_{1}$ group. The findings of present study are in accordance with Shohe et al. (2019) who reported significant $(\mathrm{P}<0.05)$ improvement in body weight, weight gain, feed intake, feed conversion ratio and performance index in the treatment group supplemented with turmeric powder. Arslan et al. (2017) also reported significant $(\mathrm{P}<0.05)$ improvement in body weight, weight gain, feed conversion ratio in the treatment group supplemented with turmeric powder. Similarly, Awad et al. (2009), reported significant $(\mathrm{P}<0.05)$ improvement in body weight, daily weight gain and feed conversion ratio due to synbiotic supplementation. Ashayerizadeh et al. (2011) also observed significant effect on daily weight gain of broiler with supplementation of synbiotic. Popovic et al. (2015) observed significant $(\mathrm{P}<0.05)$ effect body weight, feed intake and feed conversion ratio due synbiotic supplementation. The results obtained in study corroborate well with the findings of Kohri (2020) who observed highly significant $(\mathrm{P}<0.01)$ effect on performance index and protein efficiency ratio due to supplementation of synbiotic powder in broilers.

\section{Mortality}

The mortality of chicks among various treatment groups are presented in Table (2). Lowest mortality percent was observed in $\mathrm{T}_{3}$ and $\mathrm{T}_{5}$ group while highest mortality was observed in $\mathrm{T}_{1}$ group fed with basal diet.
Table 2: Mortality rate of broilers at the whole experimental period (Percentage)

\begin{tabular}{llllll}
\hline \multirow{2}{*}{ Parameter } & \multicolumn{5}{c}{ Treatment groups } \\
\cline { 2 - 6 } & $\mathbf{T}_{\mathbf{1}}$ & $\mathbf{T}_{2}$ & $\mathbf{T}_{3}$ & $\mathbf{T}_{4}$ & $\mathbf{T}_{\mathbf{5}}$ \\
\hline Mortality (\%) & 16.67 & 6.67 & 3.33 & 6.67 & 3.33 \\
\hline
\end{tabular}

$\mathrm{T}_{1}$ : Control; $\mathrm{T}_{2}$ : Antibiotic @ 0.02\%; $\mathrm{T}_{3}$ : Turmeric powder @ 0.5\%; $\mathrm{T}_{4}$ : Synbiotic@0.05\%; $\mathrm{T}_{5}$ : Turmeric@0.25\%+Synbiotic @ $0.025 \%$.

Results of the present study regarding per cent mortality well corroborate with the findings of Al-Jaleel (2012), Umaram (2018) also reported reduced mortality percent with supplementation of turmeric powder. Similarly, Abdel-Raheem and Abd-Allah (2011), Popovic et al. (2015) who observed reduced mortality due to synbiotic supplementation.

\section{CONCLUSION}

It can be concluded that as an alternative to antibiotics supplementation Turmeric @ 0.25\% + Synbiotic @ $0.025 \%$ can be used to increase the growth performance and to reduce mortality of broiler chicken in the postantibiotic period.

\section{REFERENCES}

A.O.A.C. 2016. Official method of analysis. $15^{\text {th }}$ Edn., Association of Official Analytical Chemists, Washington, D.C., U.S.A.

Abd El-Hack, M.E.A., Samak, D.H., Noreldin, A.E. ElNaggar, K. and Abdo, M. 2018. Probiotics and plant-derived compounds as eco-friendly agents to inhibit microbial toxins in poultry feed: a comprehensive review. Environ. Sci. Poll. Res., 25: 31971-31986.

Abd El-Moneim, A.E. and Sabic. E.M. 2019. Beneficial effect of feeding olive pulp and Aspergillus awamori on productive performance, egg quality, serum/yolk cholesterol and oxidative status in laying Japanese quails. J. Anim. Feed Sci., 28: $52-61$.

Abdel-Moneim, A.M.E., Selim, D.A., Basuony, H.A., Sabic, E.M., Saleh, A.A. and Ebeid, T.A. 2020. Effect of dietary supplementation of Bacillus subtilis spores on growth performance, oxidative status, and digestive enzyme activities in Japanese quail birds. Trop. Anim. Health Prod., 52: 671-680. 
Abdelnour, S.A., Abd El-Hack, M.E., Arif, M., Khafaga A.F. and Taha A.E. 2019. The application of the microalgae Chlorella spp. as a supplement in broiler feed Worlds Poult. Sci.J., 75(2): 305-318.

Abdel-Raheem, S.M. and Abd-Allah, S.M.S. 2011. The effect of single or combined dietary supplementation of mannan oligosaccharide and probiotics on performance and slaughter characteristics of broilers. Int. J. Poult. Sci., 10(11): 854-862.

Adil, S. and margay, S.N. 2012. Impact and manipulation of gut microflora in poultry. A review. J. Anim. Vet. Adv., 11: 873877.

Akbarian, A., Golian, A., Kermanshahi, H., Gilani, A. and Moradi, S. 2012. Influence of turmeric rhizome and black pepper on blood constituents and performance of broiler chickens. Afr. J. Biotechnol., 11(34): 8606-8611.

Alagawany M., Elnesr S.S., Farag M.R., El-Hack, A., Mohamed, E., Khafaga, A.F., Taha A.E., Tiwari, R., Yatoo, M.I., Bhatt, P., Khurana S.K. and Dhama K. 2019. Omega-3 and Omega-6 Fatty Acids in Poultry Nutrition: Effect on Production Performance and Health. Animals (Basel), 9(8): 573.

Alagawany, M., Abd El-Hack, M.E., Farag, M.R., Sachan, S., Karthik, K. and Dhama, K. 2018. The use of probiotics as eco-friendly alternatives for antibiotics in poultry nutrition. Environ. Sci. Poll. Res., 25: 10611-10618.

Alagawany, M., Abd El-Hack, M.E., Arif, M., and Ashour, E.A. 2016. Individual and combined effects of crude protein, methionine, and probiotic levels on laying hen productive performance and nitrogen pollution in the manure pollution in the manure. Environ. Sci. Poll. Res., 23: 22906-22913.

Alagawany, M., Elnesr, S.S., Farag, M.R., El-Hack, A., Mohamed, E., Khafaga, A.F., Taha A.E., Tiwari, R., Yatoo, M.I., Bhatt, P., Marappan, G. and Dhama K. 2019b. Use of Licorice (Glycyrrhiza glabra) Herb as a Feed Additive in Poultry: Current Knowledge and Prospects. Animals (Basel), 9(8): 536.

Al-Jaleel, R.A. 2012. Use of turmeric (Curcuma longa) on the performance and some physiological traits on the broiler diets. Iraqi. J. Vet. Med., 36(1): 51-57.

Angelakis, E., Merhej V. and Raoult, D. 2013. Related actions of probiotics and antibiotics on gut microbiota and weight modification. Lancet. Infect. Dis., 13: 889-899.

Arif, M., Hayat, Z., Abd El-Hack, M.E., Saeed, M., Imran, H.M., Alowaimer, A.N., Saadeldin, Taha, A.E. and Swelum, A.A. 2019. Impacts of supplementing broiler diets with a powder mixture of black cumin, moringa and chicory seeds. S. Afr. J. Anim. Sci., 49: 564-572.

Arslan, M., Haq, A., Ashraf, M., Iqbal, J. and Mund, M.D. 2017. Effect of turmeric (Curcuma longa) supplementation on growth performance, immune response, carcass characteristics and cholesterol profile in broilers. Veterinaria, 66(1): 16-19.

Ashayerizadeh, A., Dabiri, N., Mirzadeh, K.H. and Ghorbani, M.R. 2011. Effect of dietary supplementation of probiotic and prebiotic on growth indices and serum biochemical parameters of broiler chickens. J. Cell Anim. Biol., 5(8): 152156.

Awad, W.A., Ghareeb, K., Abdel-Raheem, S., and Bohm, J. 2009. Effect of dietary inclusion of probiotic and synbiotic on growth performance, organ weights and intestinal histomorphology of broiler chickens. Poult. Sci., 88(1): 4956.

Aziz Mousavi, S.M.A., Seidavi, A.R., Dadashbeiki, M., KilonzoNthenge, A., Nahashon, S.N.V., Laudadio and Tufarelli, V. 2015. Effect of a synbiotic (Biomin ${ }^{\mathrm{R}}$ IMBO) on growth performance traits of broiler chickens. Eur. Poult. Sci., 79: $1-15$.

Dankowiakowska, A., Kozlowska, I. and Bednarczyk M. 2013. Probiotics, prebiotics and snybiotics in Poultry-mode of action, limitation and achievements. J. Cent. Euro. Agric., 14(1): 467-478.

Dhama, K., Chakraborty, S. and Tiwari, R. 2013. Panchgavya therapy (Cowpathy) in safeguarding health of animals and humans: A review. Res. Opin. Anim. Vet. Sci., 3: 170-178.

Dhama, K., Verma, V., Sawant, P.M., Tiwari, R., Vaid, R.K. and Chauhan, R.S. 2011. Applications of probiotics in poultry: Enhancing immunity and beneficial effects on production performances and health: A review. J. Immunol. Immunopathol., 13: 1-19.

Farghly, M.F.A., Ahmad, E.A.M., Alagawany, M., Abd ElHack, M.E., Ali, R.A.M., Elnesr, S.S., Taha, A.E. and Salah A.S. 2018. Use of some nutritional supplements in drinking water of growing turkeys during $1^{\text {st }}$ month of age and their effect on performance, meat quality, blood profile and antioxidant status. J. Anim. Physiol. Anim. Nutr., 102(6): 1625-1633.

Hosseini-Vashan, S.J., Golian, A., Yaghobfar, A., Zarban, A., Afzali, N. and Esmaeilinasab, P. 2012. Antioxidant status, immune system, blood metabolites and carcass characteristic of broiler chickens fed turmeric rhizome powder under heat stress. Afr. J. Biotechnol., 11(94): 16118-16125.

Hussein, S.N. 2013. Effect of Turmeric (Curcuma longa) powder on growth performance, carcass traits, meat quality, and serum biochemical parameters in broilers. J. Adv. Biomed. Pathobiol. Res., 3(2): 25-32.

Kantas, D., Papatsiros, V.G., Tassis, P.D., Giavasis, I., Bouki, P., and Tzika, E.D. 2015. A feed additive containing Bacillus toyonensis (Toyocerin $\left.{ }^{\circledR}\right)$ protects against enteric pathogens in post-weaning piglets. J. Appl. Microbiol., 118(3): 727-738. 
Kohri. 2020. Effect of dietary supplementation of tulsi (Ocimum sanctum) and synbiotic powder as feed additives on growth performance and nutrient utilization in broiler chicks. M.V.Sc. thesis, Rajasthan University of Veterinary and Animal Sciences, Bikaner.

Kramer, C.Y. 1956. Extension of multiple range tests to group means with unequal numbers of replications. Biometrics, 12: 307-310.

Mahima, Ingle, A.M., Verma, A.K., Tiwari, R. and Karthik K. 2013. immunomodulators in day to day life: A review. Pak. $J$. Biol. Sci., 16: 826-843.

Mahima, Rahal, A., Deb, R., Latheef S.K. and Samad, H.A. 2012. Immunomodulatory and therapeutic potentials of herbal, traditional/indigenous and ethnoveterinary medicines. Pak. J. Biol. Sci., 15: 754-774.

Nouzarian, R., Tabeidian, S.A., Toghyani, M., Ghalamkari, G. and Toghyani, M. 2011. Effect of turmeric powder on performance, carcass traits, humoral immune responses, and serum metabolites in broiler chickens. J. Anim. Feed Sci., 20(3): 389-400.

Popovic, S.J., Kostadinovic, L.M., Puvaca, N.M., Levic, J.D., Duragic, O.M., Kokic, B.M. and Vranjes, M.V. 2015. Effect of synbiotic on growth and antioxidant status of blood in broiler chicken. Food Feed Res., 42(2): 163-169.

Shewita, R.S. and Taha A.E. 2018. Influence of dietary supple- mentation of ginger powder at different levels on growth performance, haematological profiles, slaughter traits and gut morphometry of broiler chickens. S. Afr. J. Anim. Sci. 48: 997-1008.

Shohe, A., Vidyarthi, V.K. and Zuyie, R. 2019. Performance of Broiler Chicken on Diet Supplemented with Turmeric Powder (Curcuma longa). Livest. Res. Int., 7(2): 77-82.
Soomro, R.N., Abd El-Hack, M.E., Shah, S.S., Taha, A.E., Alagawany, M., Swelum, A.A., Hussein, E.O.S. Ba-Aawdh, H.A., Saadeldin, I., El-Edel, M.A. and Tufarelli, V. 2019. Impact of restricting feed and probiotic supplementation on growth perfor- mance, mortality and carcass traits of meattype quails. Anim. Sci. J., 90: 1388-1395.

SPSS 2018. Statistical package for social sciences, version 20. Procedure and Facilities for Research. McGraw Hill Book Co., New York.

Taha, A.E., Hassan, S.S., Shewita, R.S., El-seidy, A.A., Abd ElHack, M.E., Hussein, E.S.O., Saadeldin, I.M., Swelum, A.A. and El-Edel, M.A. 2019. Effects of supplementing broiler diets with coriander seed powder on growth performance, blood haematology, ileum microflora and economic efficiency. J. Anim. Physiol. Anim. Nutr., 103(5): 1474-1483.

Umaram. 2018. Effect of dietary supplementation of turmeric (Curcuma longa) and ginger (Zingiber officinale) powders as feed additives on growth performance and nutrient utilization in broilers. M.V.Sc. thesis, Rajasthan University of Veterinary and Animal Sciences, Bikaner.

Willems, O.W., Miller, S.P. and Wood, B.J. 2013. Aspects of selection for feed efficiency in meat producing poultry. Worlds Poult. Sci. J., 69(1): 77-88.

Youssef, A.W., Hassan, H.M.A., Ali, H.M. and Mohamed, M.A. 2013. Effect of probiotics, prebiotics and organic acids on layer performance and egg quality. Asian J. Poult. Sci., 7(2): $1-10$. 